\title{
MORPHOLOGICAL CHANGES IN GEESE AFTER EXPERIMENTAL AND NATURAL INFECTION WITH MYCOBACTERIUM AVIUM SEROTYPE 2
}

\author{
M. PAVLAS, VLASTA PATLOKOVÁ and J. ZAJÍČEK* \\ Veterinary Research Institute, 62132 Brno \\ *District Veterinary Service Centre, České Budějovice
}

Received February 14, 1983

\begin{abstract}
Pavlas M., Vlasta Patloková and J. Zajíček: Morphological Changes in Geese after Experimental and Natural Infection with Mycobacterium avium Serotype 2. Acta vet. Brno, 52, 1983: 163-167.

Pathomorphological changes in two groups of 10 geese infected experimentally with Mycobacterium avium serotype 2 by either the intravenous or the oral route were localized most frequently in the liver. The resistance of geese to $M$. avium was high particularly in the group infected orally where tuberculous lesions were demonstrated in 3 birds in the liver and in one bird each in the intestine, lung and spleen. Similar results were obtained in slaughter geese infected naturally with $M$. avium. Serological examination by means of rapid agglutination with blood and serum proved a better diagnostic tool than tuberculin testing; it detected tuberculosis in 80 per cent of intravenously infected birds and in 20 per cent of orally infected birds with tuberculosis of the liver but failed to do so in geese having solitary tubercles in the liver, spleen or lung after oral infection. The high resistance of geese to $M$. avium particularly after oral infection does not exclude the possibility of their contracting avian tuberculosis. However, massive infection is required to produce the disease and the transfer of infection is less frequent than in gallinaceous birds.
\end{abstract}

Mycobacterium avium, goose, susceptibility, morphological changes, diagnosis, avian tuberculosis.

Mycobacterium avium is presently the most important pathogenic mycobacterium in the epizootiology of tuberculosis in birds. Among water-fowls, geese and ducks are generally regarded as relatively resistant to avian tuberculosis. Tuberculous lesions in geese and ducks have been found mainly in the liver, intestine and spleen, and less frequently in other organs. Tuberculosis of bones is very rare in geese (Klimeš 1970). Of geese showing positive reactions to avian tuberculin, 94.4 per cent were reported to have tuberculous lesions in the liver, 27.7 per cent in the lung, 22.2 per cent in the spleen, 11.1 per cent in the intestine and 5.5 per cent in the kidney (Shchepilov 1957). In the Czech Socialist Republic, a study on geese including slaughter and dead birds from large and small flocks showed that in tuberculous geese, 96 per cent of tuberculous lesions were in the spleen, 48 per cent in the liver and only occasional lesions were found in the lung and intestine (Rachač 1981). Liver and spleen lesions were also most frequent in geese after experimental infection with $M$. avium. Histological changes in the liver and spleen were demonstrated as early as 12 days and necrotic foci 21 days after infection, whereas the intestine showed only solitary tuberculous lesions (Černy 1982). The last-named investigator found no tuberculous lesions in ducks exposed to avian tuberculosis by contact for 250 days. In the U.S.S.R. natural infection with $M$. avium in geese and ducks kept together with tuberculous birds was described by Matyzhev (1958).

On gross examination, tuberculous lesions in slaughter or dead geese may be confused with non-specific changes produced by causative agents of aspergillosis, pseudotuberculosis and salmonellosis as well as by micrococci and further agents of non-specific disease such as leucosis and sarcomatosis. Flešár et al. (1976) examining 519 specimens from slaughter geese with gross le- 
sions suspicious of tuberculosis confirmed the specificity of the lesions by microscopical examination in 127 specimens and by culture in 70 specimens. They found these changes in 5.8 per cent of slaughter geese and demonstrated tuberculosis in one-fourth of them; the incidence of specific lesions in the geese was considerably higher than the average incidence of tuberculosis among slaughter poultry in Czechoslovakia.

In the light of the aforementioned observations it was recommended to elucidate the aetiology of necrotic changes particularly in the liver and spleen by comprehensive laboratory examination.

To elucidate the susceptibility of geese to avian tuberculosis, we used experimental infection of geese with $M$. avium by oral and intravenous routes. In geese with naturally occurring tuberculosis we assessed the incidence, extent and localization of specific lesions.

\section{Materials and Methods}

For experimental infection, 25 geese averaging $2.5 \mathrm{~kg}$ in body mass were used. Ten of them were infected with $M$. avium strains T 66 and T 175 intravenously, 10 were infected with the same strains orally and the remaining 5 birds were used as controls. Before the start of the experiment all the $15^{\circ}$ geese were tested intradermally with PPD avian tuberculin at 2000 TU and examined serologically by means of agglutination with negative results.

The two infection strains had proved virulent in bioassay on pullets inoculated intramuscularly with $1 \mathrm{mg}$ of culture. Their antigenic properties identified them as M. avium serotype 2 .

For intravenous infection, a dose of $0.5 \mathrm{mg}$ of a semiwet culture of strains T 66 and 6175 homogenized in $0.5 \mathrm{ml}$ sterile saline per bird was used. For oral infection, rolls $(1.5 \mathrm{~cm}$ in diameter and $4 \mathrm{~cm}$ in length) were prepared from a feed mixture, air-dried and then moistened with the mycobacterial suspension at the rate of $1 \mathrm{mg}$ culture in $1 \mathrm{ml}$ saline immediately before being fed to the geese. Oral infections was carried out on five consecutive days using $1 \mathrm{mg}$ of culture per bird per day.

The geese were observed for their general health status including body mass, response to avian tuberculin and humoral antibody level at monthly intervals. Tuberculin was inoculated intradermally into the submandibular region and the web. Humoral antibodies were detected by rapid agglutination with blood and serum. The experimental geese that did not die during 4 months after infection, and controls, were slaughtered at the end of this period. All the birds were subjected to patho-anatomical and bacteriological examination. The organs were examined by culture regardless of the pathomorphological findings.

Examination for tuberculosis in slaughter geese was carried out in 1500 birds. The aetiology of gross changes suspicious of tuberculosis was clarified by microscopical examination of tissue smears stained according to Ziehl-Neelsen and by culture of altered parts of the organs using Petragnani's medium, Stonebrink's medium and Šula's fluid medium. For decontamination of the test samples, $1 \mathrm{n} \mathrm{HCl}$ was employed. After $\mathrm{HCl}$ treatment for 20 minutes the suspension was neutralized with $2 \mathrm{n} \mathrm{NaOH}$. The cultures obtained were observed for their ability to grow on solid and fluid media at 25,37 and $42{ }^{\circ} \mathrm{C}$. Mycobacterial strains suitable for serotyping were examined for their antigenic structure by means of agglutination (Schaefer 1967).

\section{Results}

During the first month after infection the nutritional status of geese in the experimental groups was the same as in the control group. In the intravenously infected group, however, an overall mean body mass loss of $0.01 \mathrm{~kg}$ per bird was recorded for the whole experimental period. On the other hand, the nutritional status of geese infected orally improved with advancing age and was classified as very good; their overall mean gain for the whole experimental period was $1.2 \mathrm{~kg}$ per bird as against $1.08 \mathrm{~kg}$ per bird in the control group.

Intradermal tuberculin testing detected no infected animals. On the other hand, examination for humoral antibodies by means of rapid agglutination proved to be a better diagnostic tool. With this method, positive reaction was shown by 80 per cent of intravenously infected geese and by 20 per cent of orally infected birds with tuberculosis of the liver 3 months after infection.

In the group of 10 geese infected intravenously, 4 birds died within two months 
of infection and 2 other birds during the next two months. The remaining 4 geese were slaughtered 4 months after infection. Pathomorphological examination revealed tuberculosis of the liver in all the 10 birds. A survey of patho-anatomical changes found in individual organs is presented in Table 1. Microscopical and cultural examination demonstrated mycobacteria very frequently even in organs with negative findings on gross examination. This applies particularly to the kidney and bone marrow where $M$. avium was demonstrated by culture in 7 and 8 geese, respectively, out of 10 birds.

Table 1

Patho-anatomical changes and bacteriological findings in geese infected experimentally with Mycobacterium avium

\begin{tabular}{|c|c|c|c|c|c|c|c|c|}
\hline \multirow{3}{*}{$\begin{array}{l}\text { No. } \\
\text { birds }\end{array}$} & \multirow{3}{*}{$\begin{array}{l}\text { No. of } \\
\text { birds } \\
\text { that } \\
\text { died }\end{array}$} & \multirow{3}{*}{$\begin{array}{l}\text { Route of } \\
\text { infection }\end{array}$} & \multirow{3}{*}{$\begin{array}{l}\text { Organ with } \\
\text { gross lesions }\end{array}$} & \multirow{3}{*}{$\begin{array}{l}\text { No. birds } \\
\text { with lesions } \\
\text { in the parti- } \\
\text { cular organ }\end{array}$} & \multicolumn{4}{|c|}{ Bacteriological examination for mycobacteria } \\
\hline & & & & & \multicolumn{2}{|c|}{$\begin{array}{l}\text { Microscopical } \\
\text { examination }\end{array}$} & \multicolumn{2}{|c|}{ Culture } \\
\hline & & & & & $\begin{array}{l}\text { No. birds } \\
\text { positive }\end{array}$ & $\begin{array}{l}\text { No. birds } \\
\text { negative }\end{array}$ & $\begin{array}{l}\text { No. birds } \\
\text { positive }\end{array}$ & $\begin{array}{c}\text { No. birds } \\
\text { negative }\end{array}$ \\
\hline 10 & 6 & $i / v$ & $\begin{array}{l}\text { Spleen } \\
\text { Liver } \\
\text { Intestine } \\
\text { Lung } \\
\text { Heart } \\
\text { Kidney } \\
\text { Bone marrow }\end{array}$ & $\begin{array}{r}7 \\
10 \\
3 \\
7 \\
1 \\
0 \\
2\end{array}$ & $\begin{array}{r}10 \\
10 \\
3 \\
6 \\
1 \\
6 \\
7\end{array}$ & $\begin{array}{l}0 \\
0 \\
0 \\
1 \\
0 \\
3 \\
1\end{array}$ & $\begin{array}{r}10 \\
10 \\
3 \\
7 \\
1 \\
7 \\
8\end{array}$ & $\begin{array}{l}0 \\
0 \\
0 \\
0 \\
0 \\
2 \\
0\end{array}$ \\
\hline 10 . & 0 & oral & $\begin{array}{l}\text { Spleen } \\
\text { Liver } \\
\text { Intestine } \\
\text { Lung } \\
\text { Heart } \\
\text { Kidney } \\
\text { Bone marrow }\end{array}$ & $\begin{array}{l}1 \\
5 \\
1 \\
1 \\
0 \\
0 \\
0\end{array}$ & $\begin{array}{l}1 \\
3 \\
1 \\
0 \\
0 \\
0 \\
0\end{array}$ & $\begin{array}{l}9 \\
7 \\
1 \\
2 \\
0 \\
1 \\
0\end{array}$ & $\begin{array}{l}4 \\
3 \\
1 \\
1 \\
0 \\
0 \\
0\end{array}$ & $\begin{array}{l}6 \\
7 \\
1 \\
1 \\
0 \\
1 \\
0\end{array}$ \\
\hline 5 & 0 & Controls & 0 & 0 & 0 & 5 & 0 & 5 \\
\hline
\end{tabular}

Table 2

Localization of tuberculous lesions in slaughter geese infected naturally with Mycobacterium avium

\begin{tabular}{|c|c|c|c|c|c|c|c|c|c|}
\hline \multirow{3}{*}{$\begin{array}{l}\text { No. } \\
\text { birds } \\
\text { exam- } \\
\text { ined }\end{array}$} & \multirow{3}{*}{$\begin{array}{l}\text { No. birds with } \\
\text { gross lesions } \\
\text { suspicious } \\
\text { of tuberculosis }\end{array}$} & \multirow{3}{*}{$\begin{array}{l}\text { Organ with } \\
\text { lesions }\end{array}$} & \multirow{3}{*}{$\begin{array}{l}\text { No. birds with } \\
\text { lesions in the } \\
\text { particular organ }\end{array}$} & \multicolumn{6}{|c|}{ Bacteriological examination for mycobacteria } \\
\hline & & & & \multicolumn{2}{|c|}{$\begin{array}{l}\text { Microscopical } \\
\text { \& examination }\end{array}$} & \multicolumn{2}{|c|}{ Culture } & \multicolumn{2}{|c|}{$\begin{array}{l}\text { No. birds with } \\
\text { findings of }\end{array}$} \\
\hline & & & & $\begin{array}{l}\text { No. } \\
\text { birds } \\
\text { posi- } \\
\text { tive }\end{array}$ & $\begin{array}{l}\text { No. } \\
\text { birds } \\
\text { nega- } \\
\text { tive }\end{array}$ & $\begin{array}{l}\text { No. } \\
\text { birds } \\
\text { posi- } \\
\text { tive }\end{array}$ & $\begin{array}{l}\text { No. } \\
\text { birds } \\
\text { nega- } \\
\text { tive }\end{array}$ & $\begin{array}{l}\text { M. } \\
\text { avium } \\
2\end{array}$ & $\begin{array}{c}\text { M. } \\
\text { avium } \\
2,3\end{array}$ \\
\hline 1500 & 40 & $\begin{array}{l}\text { Spleen } \\
\text { Liver } \\
\text { Intestine } \\
\text { Lung } \\
\text { Heart }\end{array}$ & $\begin{array}{r}27 \\
21 \\
2 \\
1 \\
1\end{array}$ & $\begin{array}{r}14 \\
6 \\
1 \\
0 \\
0\end{array}$ & $\begin{array}{r}13 \\
15 \\
1 \\
1 \\
1\end{array}$ & $\begin{array}{r}18 \\
10 \\
1 \\
1 \\
1\end{array}$ & $\begin{array}{r}9 \\
11 \\
1 \\
0 \\
0\end{array}$ & $\begin{array}{r}14 \\
8 \\
1 \\
1 \\
1\end{array}$ & $\begin{array}{l}4 \\
2 \\
0 \\
0 \\
0\end{array}$ \\
\hline
\end{tabular}

In the group of 10 geese infected orally, 5 birds had gross lesions in the liver. Only in 3 of them the specificity of the gross changes was confirmed by microscopical examination and culture. Solitary specific changes in the form of tubercles about the size of a vetch seed were found in the spleen, the intestinal wall and lung in one bird each. 
Pathomorphological examination of 1500 slaughter geese demonstrated gross lesions suspicious of tuberculosis in 40 of them. These lesions were localized mainly in the spleen (in 27 birds) and in the liver (in 21 birds). Solitary specific tuberculous lesions were found in the intestine, lung and heart (Table 2). The specificity of gross lesions in the spleen and liver was confirmed by bacteriological examination in 66 and 47.6 per cent of the birds, respectively.

\section{Discussion}

The results reported here indicate that tuberculous lesions in geese infected orally or intravenously with $M$. avium are localized most frequently in the liver and spleen. Similar results were obtained in naturally infected slaughter geese. The findings confirm the view put forward by Klimeš (1970) and Černý (1982) that the predilection site for tuberculous lesions in $M$. avium-infected geese is the hepatic and splenic parenchyma regardless of the portal of infection.

In agreement with Flešár et al. (1967) we recommend that the specificity of gross lesions particularly in the liver and spleen should be checked by comprehensive examination.

The results extend information on the incidence of avian mycobacteria in grossly normal organs of tuberculous geese. An important observation from the food hygiene viewpoint is the frequent finding of avian mycobacteria in the bone marrow of geese with tuberculosis-affected organs.

The resistance of geese to oral infection with $M$. avium is higher than that of gallinaceous birds (Klimeš and Pavlas 1961). Heavier infections are required to produce tuberculosis in geese than in gallinaceous birds and the transfer of infection in the former is less frequent.

\section{Morfologické změny po experimentální a spontánní infekci hus Mycobacterium avium, sérotyp 2}

U hus experimentálně infikovaných Mycobacterium avium, sérotyp 2, byly patomorfologické změny nejčastěji lokalizovány $\mathrm{v}$ játrech, a to jak př̀i perorální, tak $\mathrm{i}$ intravenózní infekci. Vysoká odolnost hus $\mathrm{k} M$. avium se projevila zejména při perorální infekci, kdy pouze u 3 z 10 infikovaných zviŕat byly prokázány tuberkulózní změny v játrech a u $10 \%$ ve střevech, plicích nebo slezině. Shodných výsledkủ bylo dosaženo rovněž při hodnocení změn u jatečných hus spontánně infikovaných aviární tuberkulózou. Při posouzení spolehlivosti alergénodiagnostiky a sérologického vyšetření byly zjištěny průkaznějši výsledky rychlou aglutinací $\mathrm{s}$ krví a sérem ve srovnání s tuberkulinací. Při sérologickém vyšetření hus intravenózně infikovaných $\mathrm{s}$ orgánovou formou tuberkulózy byla zjištěna u $80 \%$ zviŕat pozitivní reakce při rychlé aglutinaci. Naproti tomu u hus infikovaných per os $\mathrm{s}$ ojedinělými tuberkly $\mathrm{v}$ játrech, slezině nebo $\mathrm{v}$ plicích byl výsledek sérologického vyšetření negativní. Při hodnocení vnímavosti hus $\mathrm{k} M$. avium byla zjištěna u těchto zviŕat vysoká odolnost, a to zejména při perorální infekci, která však nevylučuje možnost infekce zvířat $M$. avium. K nakažení je však třeba masívní infekce, přičemž přenos nákazy je méně častý ve srovnání s hrabavou drůbeží. 


\section{Морфологические изменения после экспериментальной и споптанной инфекции гусей Мусоbacterium avium, серотип 2}

У гусей, экспериментально инфицированных Mycobacterium avium, серотип 2, патоморфологические изменения были чаще всего усгановлены в печени, при пероральной и внутривенной инфекции. Высокая сопротивляемость гусей к M. avium отмечалась особенно при пероральной инфекции, когда лишь у 3 из 10 инфицированных птиц были установлены туберкулезғые изменения печени и в $10 \%$ - в кишках, легких или селезенке. Тождественных результатов было достигнуто также в ходе оценки изменений у мясопродуктивных гусей, спонтанно инфицированных птичьим туберкулезом. В ходе оценки надежности аллергенодиагностики и серологических исследований более яркие результаты были установлены быстрым аглютинированием с кровью и сывороткой по сравнению с предохранительной прививкой против туберкулеза. При серологическом исследовании гусей, внутривенно инфицированных, с туберкулезом органов, у 80 \% была установлена положительная реакция при быстром аглютинировании. В противовес этому, у гусей, инфицированных перорально, с отдельными туберкулемами в печени, селезенке или легких, результат серологического исследования был отрицательный. В ходе оценки воспримчивости гусей к $M$. avium была установлена высокая сопротивляемость, в особенности при пероральной инфекции, которая однако, не исключает возможность инфекции M. avium. Для заражения однако нужна массивная инфекция, при этом ее передача по сравнению с остальными видами домашней птицы встречается менее часто.

\section{Acknowledgement}

We wish to thank MVDr. L. Rossi, CSc., for his co-operation in the present study.

\section{References}

ČERNÝ, L.: Vývoj morfologických změn po experimentální infekci kachen a hus Mycobacterium avium. Vet. Med., Praha, 27, 1982: 95-100.

FLEŠÁR, M. - BALAŠČ́́K, J. - RENCZ, K. - KOČIŠ, J.: Štúdium výskytu a diagnostiky tuberkulózy u husí. Veterinářství, 12, 1967: 543-546.

KLIMEŠ, B.: Choroby drůbeže. Státní zemědělské nakladatelství, Praha 1970, pp. 544.

KLIMEŠ, B. - PAVLAS, M.: Př́spěvek $k$ experimentální infekci slepic tuberkulózou. Sb. vys. šk. zemědělské, Brno, B, 9, 1961: 41-62.

MATYZHEV, V. I.: O vozmožnosti zaraženija tuberkulozom kur a gusej. Tr. Orenbursk. s.-ch. inst., 10, 1960: 252-256.

RACHAČ, V.: Výskyt tuberkulózy v chovu hus. Veterinářství, 31, 1981: 353-355.

SCHAEFER, W. B.: Serologic identification of the atypical mycobacteria and its value in epidemiologic studies. Am. Rev. resp. Dis., 96, 1967: 115-118.

SHCHEPILOV, J. S.: Patologoanatomičeskije izmenenija pri tuberkuloze gusej i utok. Veterinarija, 34, 1957: 55-56. 